\title{
A Study on the Characteristics of Construction Wastes Generated from Demolition of Buildings in the Housing Environment Amelioration District
}

\author{
Byeung-Hun Son and Won-Hwa Hong \\ Department of Building Equipment and Fire Safety, Daegu Technical University, Professor \\ School of Architecture and Civil Engineering, Kyungpook National University, Professor
}

http://dx.doi.org/10.5659/AIKAR.2013.15.1.25

\begin{abstract}
The amount of construction waste increased to 176,447 ton/day in 2008 from 28,400 ton/day in 2000, a 6-fold increase in just 10 years. Such dramatic increase in the waste of concrete, asphalt concrete, wood and metals was due to demolition of old buildings as well as a great number of building redevelopment projects and hurried city industrialization. Many buildings targeted for demolition today were built in line with the government policy to provide affordable housing to citizens in the shortest time possible and consequently, said buildings underwent rapid deterioration and required periodic repairs and reconstruction. Based on the above, we predict that construction waste will continue to increase for the foreseeable future. In particular, due to limited availability of suitable space to construct apartments and residential buildings in the city, old buildings are being torn down to make space for new development, further increasing construction waste. In light of that, efforts to recycle as well as reduce generated waste are urgently required.
\end{abstract}

Keywords: Construction Waste, Demolition, Characteristics, the Housing Environment Amelioration Project

\section{INTRODUCTION}

\subsection{Background and Purpose}

Construction is a big-scale consumption industry ${ }^{1}$ that takes over $40 \%$ of natural resources, over $30 \%$ of energy and over $30 \%$ of $\mathrm{CO}_{2}$ emissions. Generated at the last stage of the building lifecycle, the final byproduct of the construction industry, construction waste took 183,351 ton/day in $2009,51.2 \%$ of the total waste generation in Korea. Given the recent construction demand from the urban concentration in the 1960's 1970's and considering the lifespan of buildings constructed in the course of rapid economic development, the generation of construction waste is expected to

\footnotetext{
Corresponding Author: Won-Hwa Hong, Professor

School of Architecture and Civil Engineering,

Kyungpook National University

Sangyeok 3-dong, Buk-gu, Daegu, 702-701, Korea

Tel:+82 539505597 e-mail : hongwh@knu.ac.kr
}

This work was supported by the National Research Foundation of Korea(NRF) grant funded by the Korea government(MEST) (No. 2011-0025645).

This is an Open Access article distributed under the terms of the Creative Commons Attribution Non-Commercial License (http://creativecommons. org/licenses/by-nc/3.0/) which permits unrestricted non-commercial use, distribution, and reproduction in any medium, provided the original work is properly cited.

\footnotetext{
${ }^{1}$ No, Seung Jun, Tae, Seong-ho, $\ulcorner$ A Study on Development of Evaluation Program of Lifecycle of Building under the Ministry of Environment(LCCO2 $)\lrcorner$,Vol. 6, No. 1, Collection of 6th Graduation Thesis Contest, Architectural Institute of Korea, 2010

increase steadily in the days to come.

Current legislation on waste management specifies that waste has to be collected separately from the construction site at the discharge stage ${ }^{2}$. In reality, however, there are no specific guidelines so that wastes are discharged together at the actual construction demolition site in more than 3 types such as waste concrete, construction waste materials, wood waste or combustible waste, mixed construction materials and hardware and ferrous materials. Mixed construction waste discharge sent to intermediate treatment companies has resulted in deteriorated and heterogeneous quality of materials recycled from construction waste and has caused problems in technology development for high quality recycled aggregates at the same time ${ }^{3}$.

In this regard, this study predicted the generation of construction waste through addition of each building in the Housing Environment Amelioration district and performed regression analysis on the total building floor area and generation of construction waste per properties of each construction waste. In addition, the study drew the most reasonable sample regression formula through test of goodness-of-fit.

\subsection{Method and Scope of the Study}

To examine the characteristic factors of construction waste in the housing environment amelioration project where it is generally difficult to predict generation of construction waste during demolition of buildings, this study selected 3 housing environment

\footnotetext{
2 Appendix 4 of Enforcement Regulation of Waste Management Act 3 the Ministry of Environment, 「A Study on Calculation of Basic Unit and Separated Collection of Construction Wastes」, 2004
} 
amelioration districts in Busan metropolitan city and Daegu metropolitan city where Housing Environment Amelioration projects have been actively performed, and surveyed 856 buildings on the field and forecasted the generation volume of construction waste through addition. Among several factors that have affected generation volume of construction waste, this study set the total building floor area that serves as standard of the basic unit for generation volume of construction waste. Figure 1 shows the study process of this study.

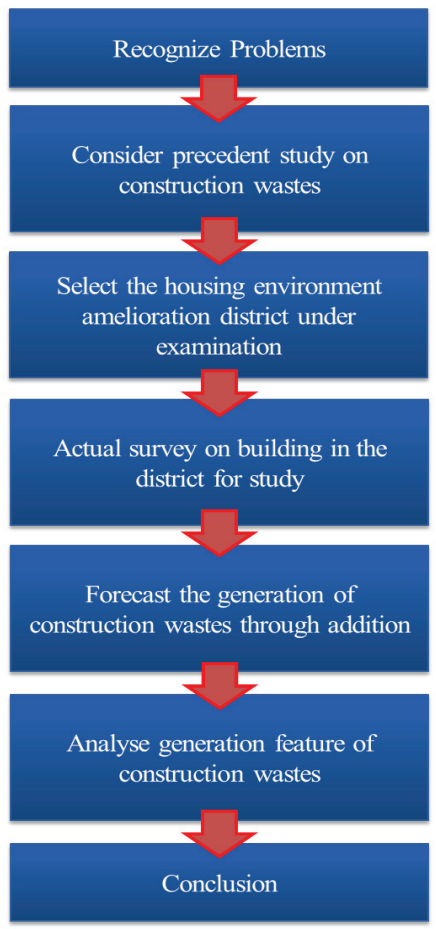

Figure 1. Study Flowchart

\section{OVERVIEW OF CONSTRUCTION WASTES AND HOUSING ENVIRONMENT AMELIORATION PROJECT}

\subsection{Definition and Generation Volume of Construction Waste}

Construction waste is defined as waste weighing over 5 ton that are generated at the construction site (from commencement to completion of works only) due to construction works corresponding to Article 2 (4) of 'The Framework Act on the Construction Industry'. Construction waste is classified into waste concrete, waste asphalt concrete, waste bricks, waste blocks and waste woods (except timber waste such as roots or branch over 5 ton), waste synthetic resins, waste textile, waste wallpapers, construction sludge (inorganic sludges that are generated in the course of construction works such as dredging works, excavation work and underground structure works, intermediate processing of waste construction materials, or wheel-washing facilities of construction work site), waste metal, waste glass, waste tile and waste ceramics, waste boards, waste panel and construction waste soil (earth, sand and gravel separated and selected among those generated in mixture of construction in the intermediate processing of construction wastes, except those in natural state), and mixed construction waste (mixture of over 2 types of construction waste from waste concrete to construction waste soil, restricted to the case when other types of construction waste are mixed with less than $5 \%$ nonflammable construction waste based on weight, mixture of combustible waste except nonflammable construction wastes with other types of construction wastes less being than $5 \%$ based on weight), and other types of wastes generated due to construction work.

Fig. 2 shows the trend of waste generation per year ${ }^{4}$.

Generation of construction waste in Korea was 12,677 ton/day in 1995 and increased to 183,351 ton/day in 2009, recording an annual average increase of 12,191 ton.

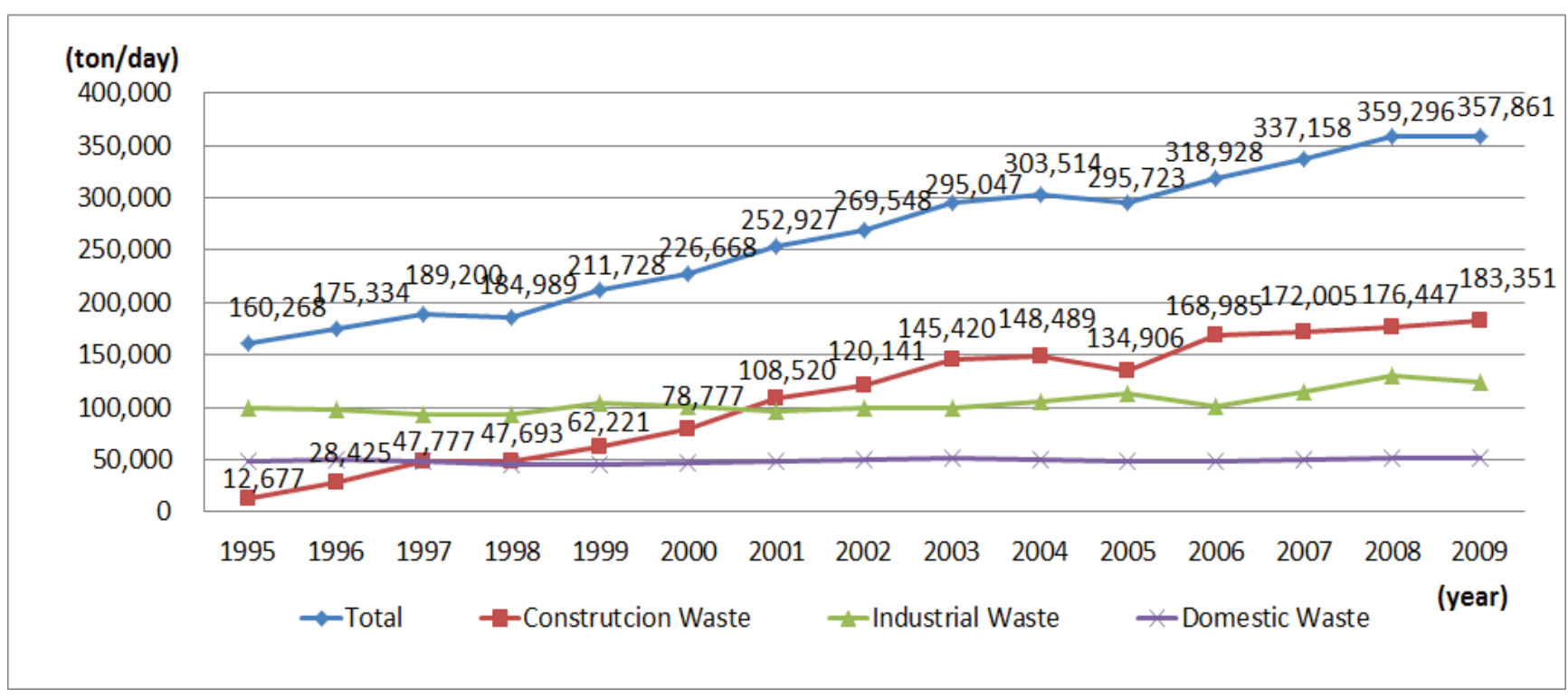

Figure 2. Trend of Waste Generation by Year

\footnotetext{
${ }^{4}$ Korea Environment Corporation, 「Generation and Treatment Status of National Wastes in 2009」, the Ministry of Environment, 2010
} 


\subsection{Basic Unit and Limitation of Construction Wastes}

The basic unit of construction waste was first applied in 1991 by the "Architectural Institute of Japan" and "Civil Engineering Association" to analyze the generation trend of construction wastes. The following formula calculates the basic unit of construction waste.

Basic Unit of Construction

$=$ Generation of Construction Waste/Area of Construction or Floor Area of Demolition

Where,

ton or kg for generation of construction waste,

$\mathrm{m}^{2}$ for area of construction or floor area of demolition.

Studies on the basic unit of construction waste in Korea as a method to forecast generation of construction waste have steadily continued since the "Proper Treatment of Waste Construction Materials and Recycling Plan" paper published by the Seoul Development Institute in 1995. It is necessary; however, to recognize that it is just material that can indirectly forecast waste indirectly forecast waste generation and has a fundamental reliability problem given that the basic unit of construction waste is defined as waste generation per unit area of construction. ${ }^{5}$

\subsection{Overview of Housing Environment Amelioration Project}

According to Article 2(2) of the City and Housing Environment Improvement Act, the environment amelioration project is carried out to improve and ameliorate housing environment in areas where lowincome city residents live in groups; key infrastructure is extremely poor; and old and deteriorated buildings are densely concentrated.

It is the area where deterioration and concentration of housing are relatively low so that residents can improve their housing individually. Housing amelioration is conducted in a local way residents obtain house financing expand, reconstruct or newly construct old housing. Local self governing bodies build reorganization infrastructure such as parks, parking lots and roads, or in joint housing constructions in which local self governing bodies or housing corporations demolish existing old and obsolete housing in the district where deterioration and concentration of housing are high, areas prone to floods or mass disasters such as fires, construct key infrastructures such roads and parks as well as apartments, and sell apartments to residents.

\section{FIELD SURVEY OF HOUSING ENVIRONMENT AMELIORATION DISTRICT}

\subsection{Overview of the Survey}

Table 1. shows the overview of housing environment amelioration district under survey.

\begin{tabular}{|c|c|c|c|c|c|}
\hline \multirow{2}{*}{$\begin{array}{l}\text { District } \\
\text { Name }\end{array}$} & \multirow{2}{*}{ Location } & \multicolumn{4}{|c|}{ Buildings under Survey } \\
\hline & & Structure & Number & Average Area & Total \\
\hline \multirow{5}{*}{$\begin{array}{l}\text { Daehyeon } \\
\text { District } 2\end{array}$} & \multirow{5}{*}{$\begin{array}{l}475-16, \\
\text { Daehyeon } \\
\text { 2-dong, } \\
\text { Buk-gu, } \\
\text { Daegu }\end{array}$} & $\mathrm{RC}$ & 31 & $144.77 \mathrm{~m}^{2}$ & \multirow{5}{*}{350} \\
\hline & & Bricks & 90 & $106.52 \mathrm{~m}^{2}$ & \\
\hline & & Blocks & 141 & $78.15 \mathrm{~m}^{2}$ & \\
\hline & & Woods & 87 & $100.54 \mathrm{~m}^{2}$ & \\
\hline & & Others & 1 & - & \\
\hline
\end{tabular}

\footnotetext{
$5\ulcorner$ A Study on Calculation of Basic Unit and Separated Collection of
} Construction Wastes」, the Ministry of Environment, 2004

\begin{tabular}{|c|c|c|c|c|c|}
\hline \multirow[b]{2}{*}{$\begin{array}{l}\text { Mandeok } \\
\text { District } 3\end{array}$} & \multirow{2}{*}{$\begin{array}{l}832, \\
\text { Mandeok } \\
\text { 3-dong, } \\
\text { Bukgu, } \\
\text { Busan }\end{array}$} & $\mathrm{RC}$ & 40 & $253.30 \mathrm{~m}^{2}$ & \multirow[b]{2}{*}{83} \\
\hline & & Blocks & 43 & $169.04 \mathrm{~m}^{2}$ & \\
\hline \multirow{5}{*}{$\begin{array}{l}\text { Shincheon } \\
\text { District 1-2 }\end{array}$} & \multirow{5}{*}{$\begin{array}{l}698-28, \\
\text { Shincheon } \\
1 \text { dong, } \\
\text { Dong-gu, } \\
\text { Daegu } \\
\text { city }\end{array}$} & $\mathrm{RC}$ & 29 & $208.22 \mathrm{~m}^{2}$ & \multirow{5}{*}{421} \\
\hline & & Bricks & 93 & $145.40 \mathrm{~m}^{2}$ & \\
\hline & & Blocks & 190 & $282.99 \mathrm{~m}^{2}$ & \\
\hline & & Woods & 107 & $144.69 \mathrm{~m}^{2}$ & \\
\hline & & Others & 2 & - & \\
\hline
\end{tabular}

The existing village in Daehyeon District 2 was the area where refugees temporarily built slate-block houses at the time of Korean War. Two story RC commercial-residential complex buildings built in the 1980's and 1990' set in $7 \mathrm{~m}$ roads along the district outskirts. The lot size at Mandeok district 3 is $12,353 \mathrm{~m}^{2}$ and sum of the total floor area of the buildings was $13,850 \mathrm{~m}^{2}$. Shincheon District 1-2 is located at Shincheon-dong, Dong-gu, Daegu and consisted of a total of 421 buildings in an area of $58,888.45 \mathrm{~m}^{2}$.

\subsection{Contents and Process of Field Survey}

Investigators visited each district, measured volume and areas for each material and member, and forecasted the generation volume of construction waste for each member or material with the estimate building construction.

Table 2. Survey Schedule

\begin{tabular}{c|c|c}
\hline District Name & Period & Field Investigator \\
\hline Daehyeon District 2 & Apr. $\sim$ May, 2005 & 20 persons \\
\hline Mandeok District 3 & Mar. $\sim$ May, 2006 & 13 persons \\
\hline Shincheon District 1-2 & Mar. $\sim$ Apr. 2007 & 24 persons \\
\hline
\end{tabular}
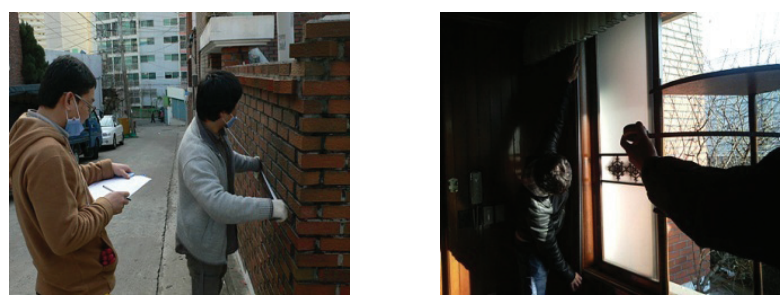

a) Measure fence length(L)

b) Measure window $\operatorname{area}(\mathrm{S})$
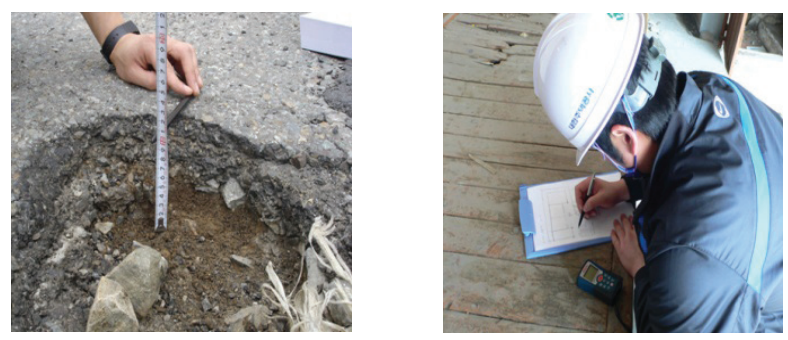

c) Measure base thickness(d)

d) Prepare field survey table

Figure 3. Photos of Design Quantity Survey through Field Measurement 
Table 3. Measurement Standards of Building per Member ${ }^{6}$

\begin{tabular}{l|l|c}
\multicolumn{1}{c|}{ Member } & \multicolumn{1}{c|}{ Structure Measurement Method } & Remarks \\
\hline General & $\begin{array}{l}\text { Lot number, area, usage, structure, } \\
\text { number of stories and heights }\end{array}$ & - \\
\hline Base & $(\mathrm{L}) \times(\mathrm{w}) \times(\mathrm{h})$ & Volume \\
\hline Stairs & $(\mathrm{L}) \times(\mathrm{w}) \times(\mathrm{d})$ & Volume \\
\hline Base $($ garden $)$ & $(\mathrm{S}) \times(\mathrm{d})$ & Volume \\
\hline Fence & $(\mathrm{L}) \times(\mathrm{d}) \times(\mathrm{h})$ & Volume \\
\hline Wall & $(\mathrm{L}) \times(\mathrm{H}) \times(\mathrm{d})$ & Volume \\
\hline $\begin{array}{l}\text { Pillar and } \\
\text { Beam }\end{array}$ & $(\mathrm{w}) \times(\mathrm{d}) \times(\mathrm{h}) \times($ places $)$ & Volume \\
\hline Slab & $(\mathrm{S}) \times(\mathrm{d})$ & Volume \\
\hline Truss & $(\mathrm{M}) \times($ places $)$ & Volume \\
\hline Ceiling Frame & $(\mathrm{M}) \times($ places $)$ & Volume \\
\hline Roof & $(\mathrm{S})$ & Area \\
\hline Windows & $(\mathrm{S})$ & Area \\
\hline Others & Measure by Material & Volume \\
\hline
\end{tabular}

$\mathrm{H}$ : total heights of each member

$\mathrm{L}$ : total length of each member

$\mathrm{M}$ : volume of each member

$S$ : total area of each member

$\mathrm{h}$ : height of each member

1 : length of each member

$\mathrm{d}$ : thickness of each member

w : width of each member

\subsection{Generation of Construction Wastes}

Table 4 shows the estimated volume of construction wastes calculated as a result of field survey.

Table 4. Estimated Volume of Construction Wastes per District

(Unit: ton)

\begin{tabular}{l|r|r|r}
\hline \multicolumn{1}{c|}{ Classification } & \multicolumn{1}{c|}{$\begin{array}{c}\text { Daehyeon } \\
\text { District 2 }\end{array}$} & $\begin{array}{c}\text { Mandeok } \\
\text { District 3 }\end{array}$ & \multicolumn{1}{c}{$\begin{array}{c}\text { Shincheon } \\
\text { District 1-2 }\end{array}$} \\
\hline Waste Concrete & 17879.02 & 6874.10 & 14181.79 \\
\hline Waste Bricks & 15200.02 & 1142.93 & 8996.99 \\
\hline Waste Blocks & 7417.79 & 9370.66 & 19905.08 \\
\hline $\begin{array}{l}\text { Waste Roofing } \\
\text { Tiles }\end{array}$ & 33.20 & 7.38 & 418.48 \\
\hline Waste Woods & 702.52 & 273.66 & 9182.80 \\
\hline Waste Resin & 1.41 & 2.02 & 2.69 \\
\hline Waste Metals & 460.75 & 619.13 & 180.30 \\
\hline Waste Glasses & 3.31 & 0.76 & 0.33 \\
\hline
\end{tabular}

\section{ANALYSIS ON CHARACTERISTIC FEATURES OF CONSTRUCTION WASTES}

\subsection{Generation Volume of Construction Wastes}

As a tool to estimate generation volume of construction waste, the basic unit of construction waste is based on building areas and

\footnotetext{
$6 \quad\ulcorner$ A Study on Preparation of Basic Unit of Construction Wastes through Comparison and Analysis of Construction Wastes before and after Demolition of Residence Building」, Jeong, Eeong Hyeok and 3 persons, Vol 23, No.10, Thesis Plan of Architectural Institute of Korea, p.p. 171, 2007
}

further classified in details according to the building structure type. Accordingly, this study reorganized the generation volume of construction waste per structure or properties of construction waste in order to examine the correlation between the total building floor area and generation of each construction waste. The following Table 5 shows the estimated generation of construction waste per building structure in the survey area.

Table 5. Estimated Volume of Construction Wastes per Structure

(Unit: ton)

\begin{tabular}{l|r|r|r|r}
\hline Classification & \multicolumn{1}{c|}{ RC } & \multicolumn{1}{c|}{ Bricks } & \multicolumn{1}{c}{ Blocks } & \multicolumn{1}{c}{ Woods } \\
\hline Waste Concrete & 14851.61 & 10597.53 & 7403.74 & 6181.96 \\
\hline Waste Bricks & 8593.40 & 15115.00 & 337.85 & 1301.27 \\
\hline Waste Blocks & 10207.68 & 4564.81 & 17742.09 & 4660.68 \\
\hline $\begin{array}{l}\text { Waste Roofing } \\
\text { Tiles }\end{array}$ & 5.55 & 56.88 & 211.88 & 190.02 \\
\hline Waste Woods & 829.09 & 1743.58 & 2967.36 & 1573.39 \\
\hline Waste Resin & 1.93 & 1.37 & 1.75 & 1.13 \\
\hline Waste Metals & 753.69 & 243.61 & 187.33 & 48.73 \\
\hline Waste Glasses & 1.66 & 0.81 & 0.55 & 0.46 \\
\hline
\end{tabular}

\subsection{Analysis on Feature of Construction Wastes}

Distribution and regression formula of waste concrete, construction wastes, waste woods, waste synthetic resins, waste metal and waste glass were expressed for each structure type.

(1) RC Building

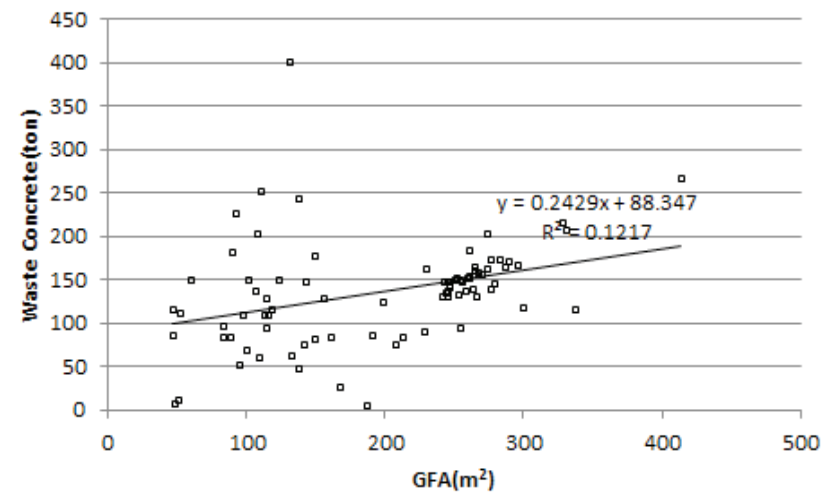

Figure 4. Distribution of Waste Concrete in RC building

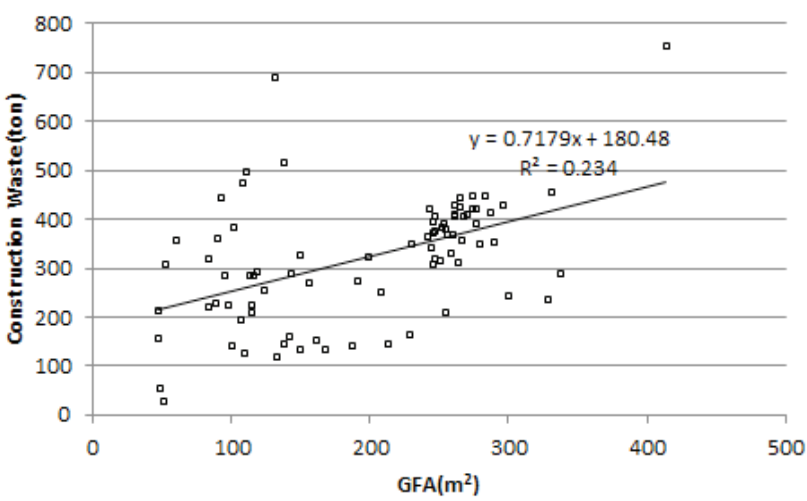

Figure 5. Distribution of Construction Wastes in RC building 


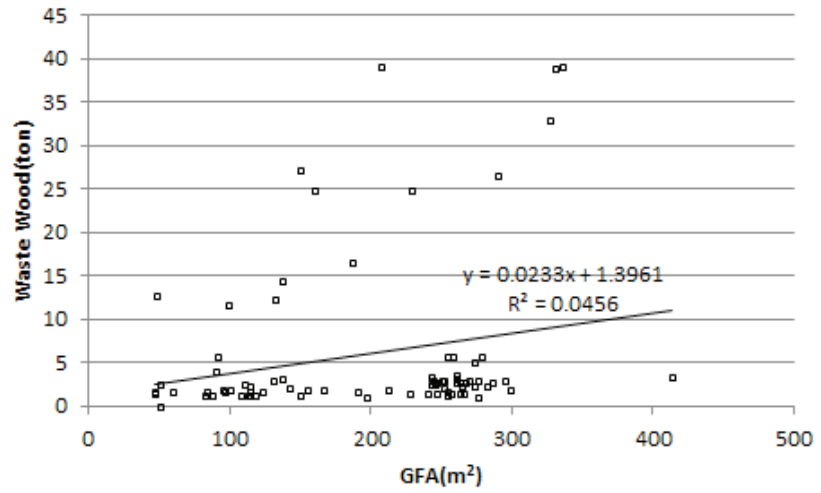

Figure 6. Distribution of Waste Wood in RC building

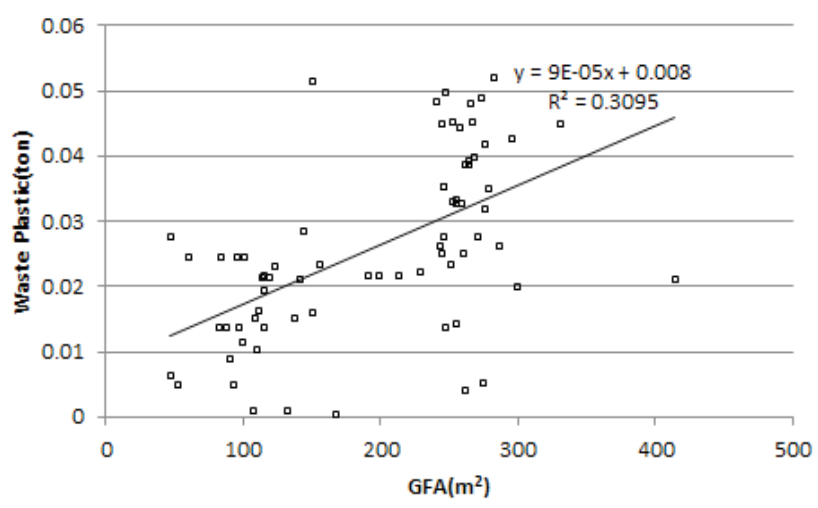

Figure 7. Distribution of Waste Synthetic Resin in RC building

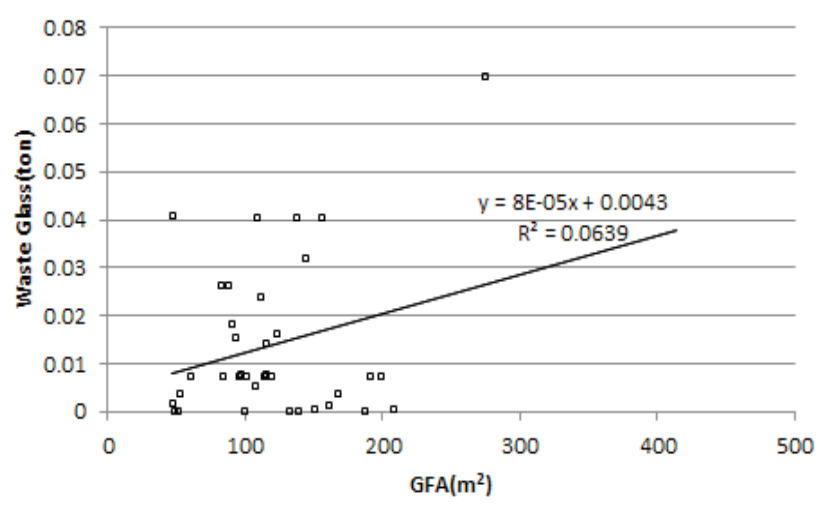

Figure 8. Distribution of Waste Glass in RC building

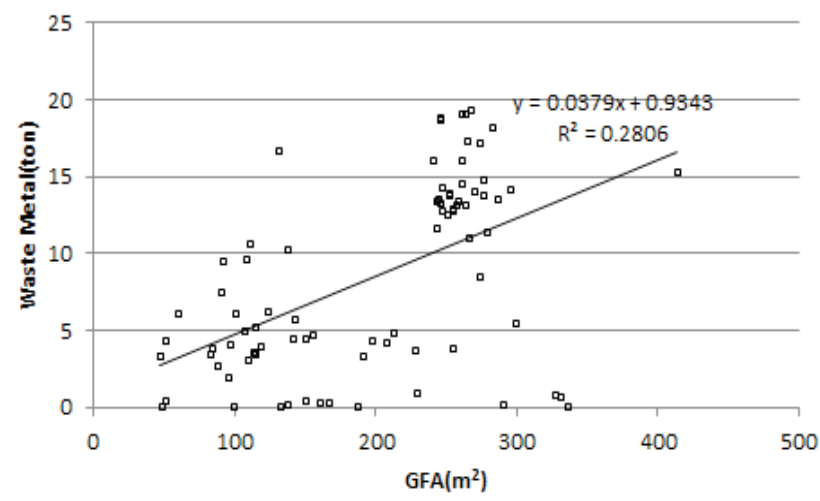

Figure 9. Distribution of Waste Metal in RC building
(2) Cement Brick Building

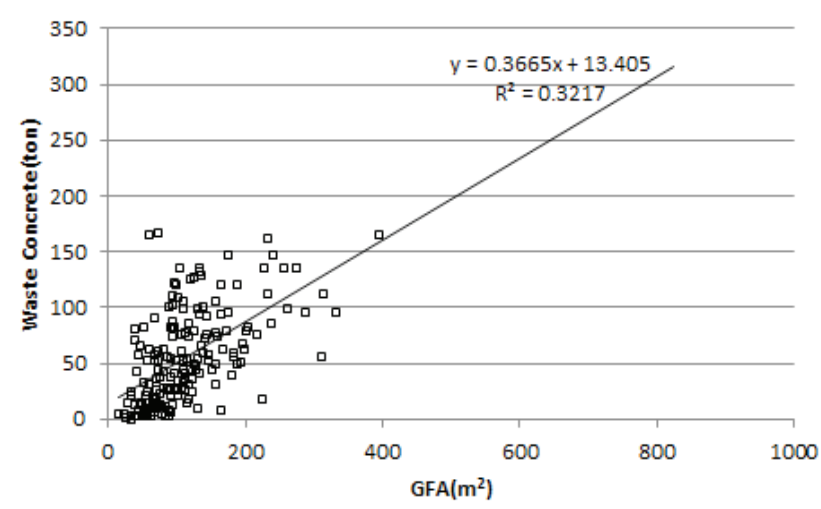

Figure 10. Distribution of Waste Concrete in brick building

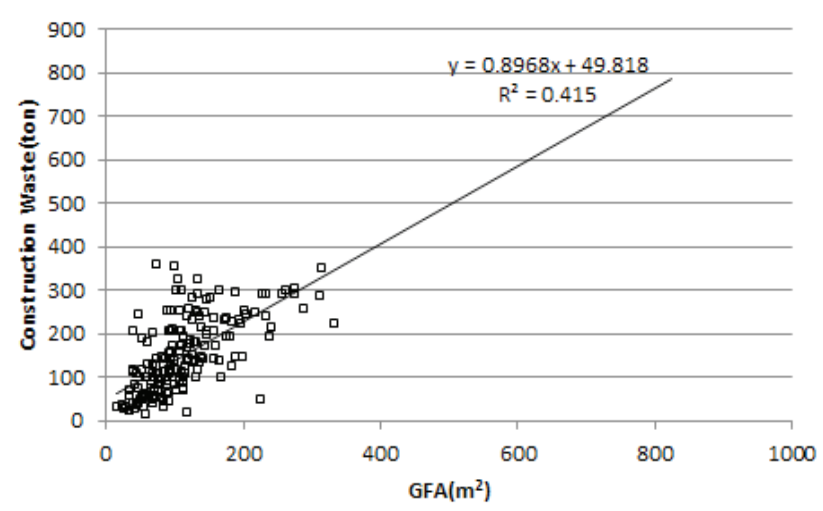

Figure 11. Distribution of Construction Wastes in brick building

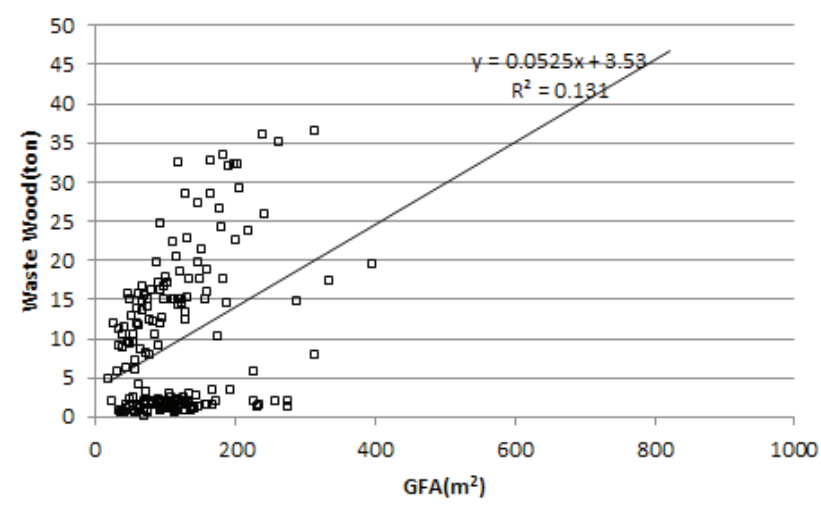

Figure 12. Distribution of Waste Wood in brick building

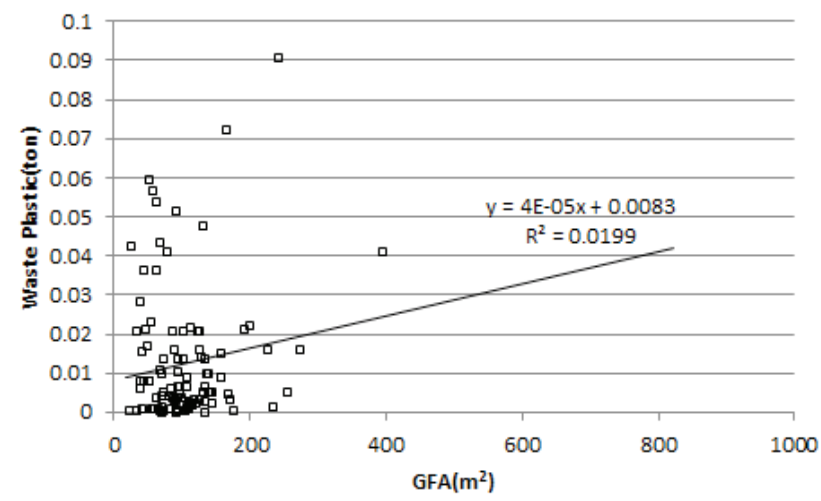

Figure 13. Distribution of Waste Plastic in brick building 


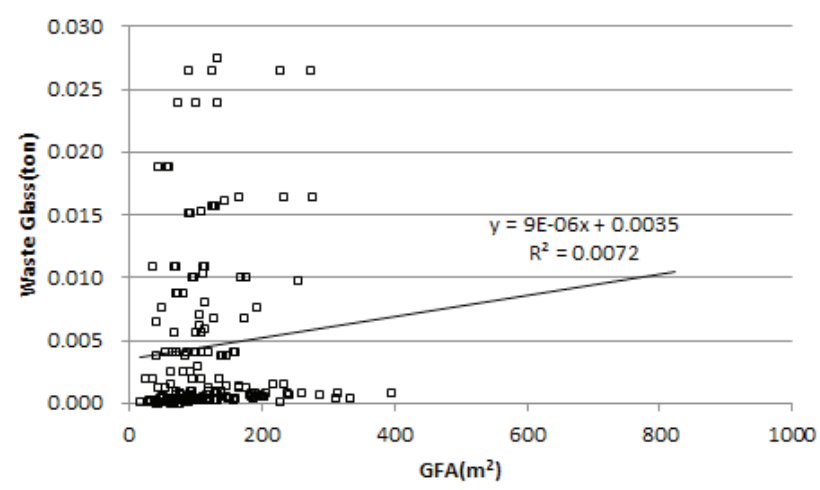

Figure 14. Distribution of Waste Glass in brick building

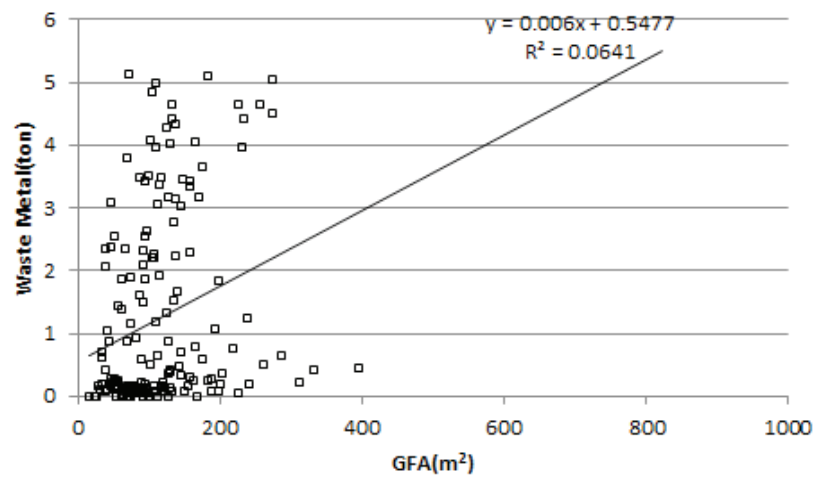

Figure 15. Distribution of Waste Metal in brick building

(3) Cement Block Building

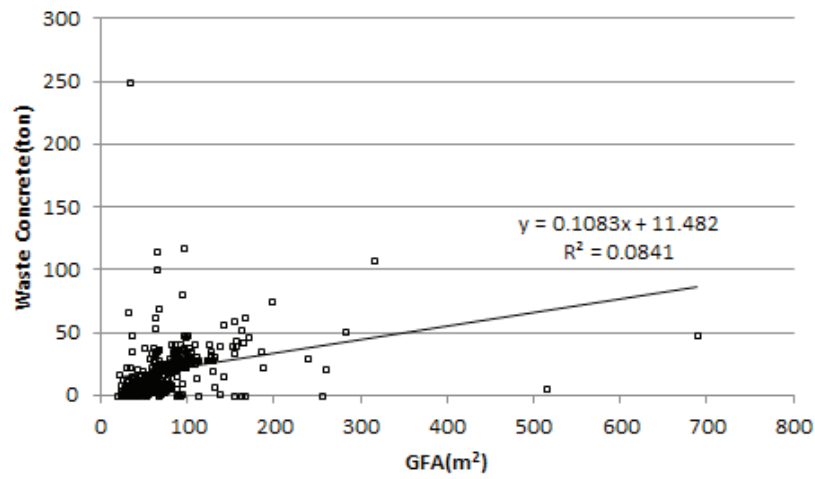

Figure 16. Distribution of Waste Concrete in block building

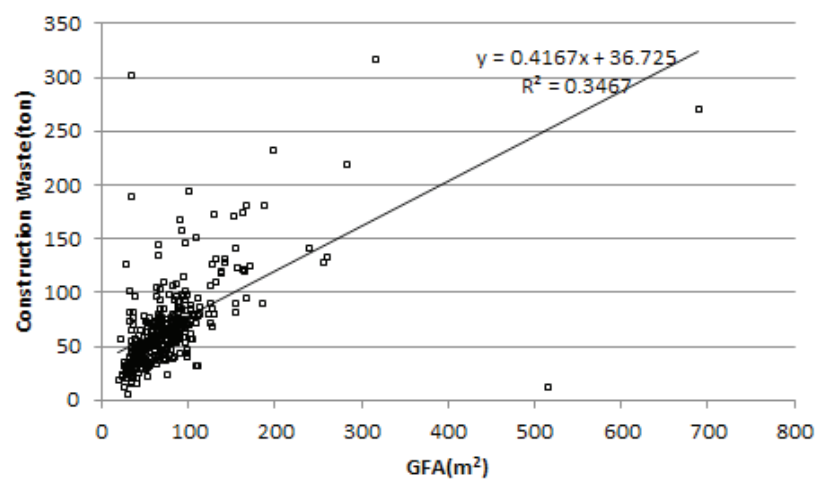

Figure 17. Distribution of Construction Wastes in block building

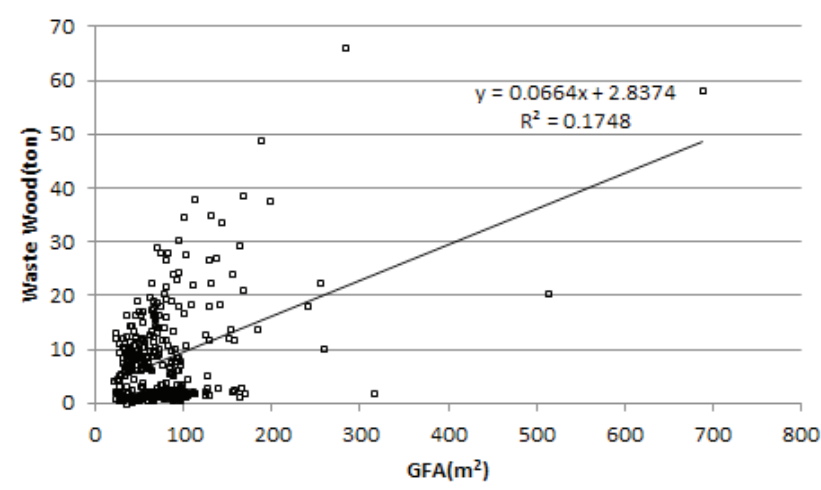

Figure 18. Distribution of Waste Wood in block building

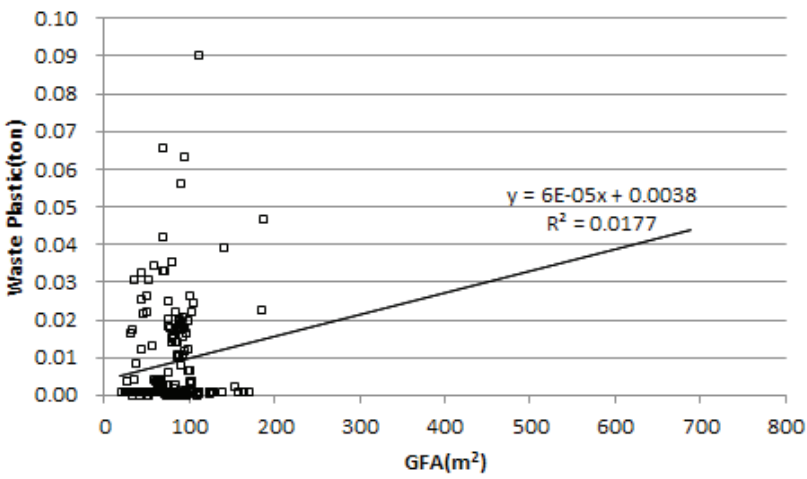

Figure 19. Distribution of Waste Plastic in block building

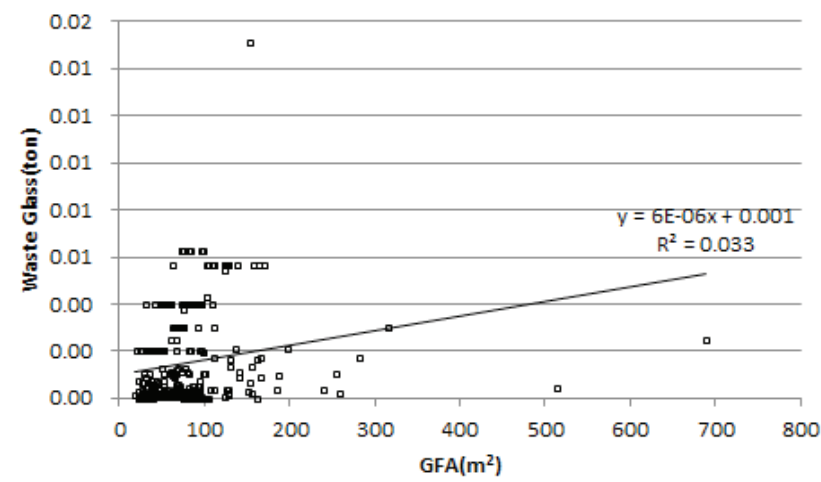

Figure 20. Distribution of Waste Glass in block building

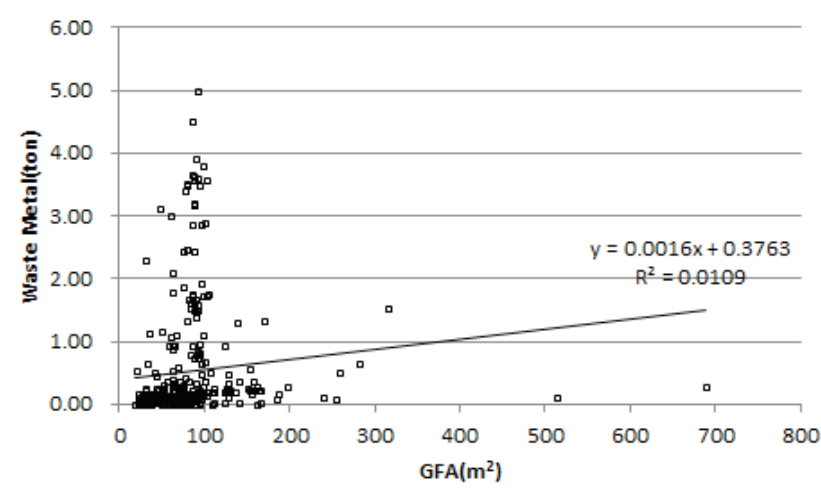

Figure 21. Distribution of Waste Metal in block building 
Distribution of each construction waste of cement blocks per property was expressed, and a regression formula was calculated from this. In general, the total floor area and generation volume of construction waste have a positive $(+)$ correlation.

(4) Estimation of Generation Volume of Construction Wastes of Timber Buildings

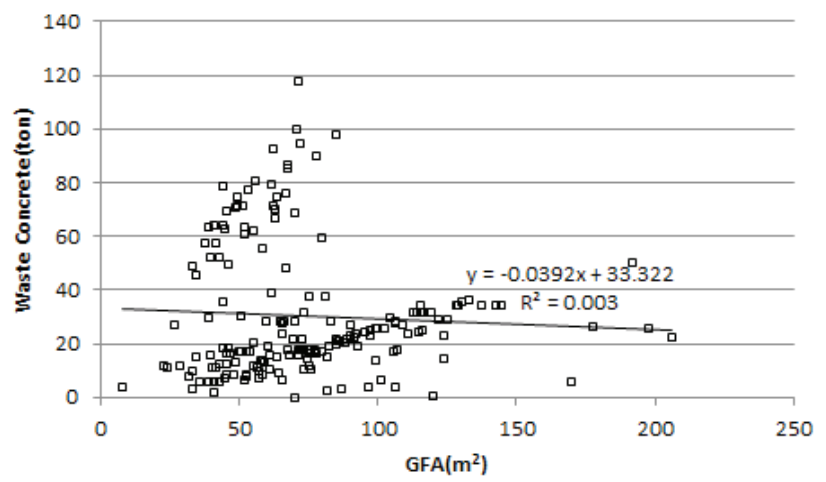

Figure 22. Distribution of Waste Concrete in wood building

In the waste concrete distribution of wood, the total floor area and waste concrete are found to have a negative (-) correlation. Accordingly, this study separated it into 2 types and prepared again depending on the percentage of generation; and the area as shown in the distribution.

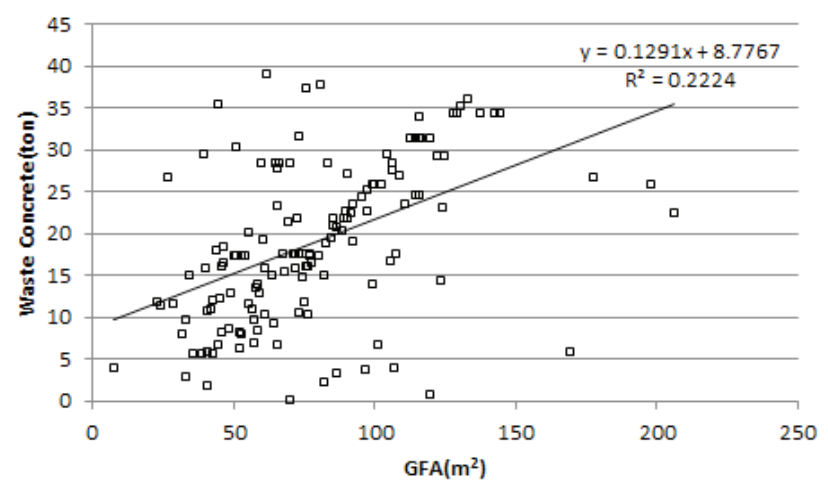

Figure 23. Distribution of Waste Concrete A-type in wood building

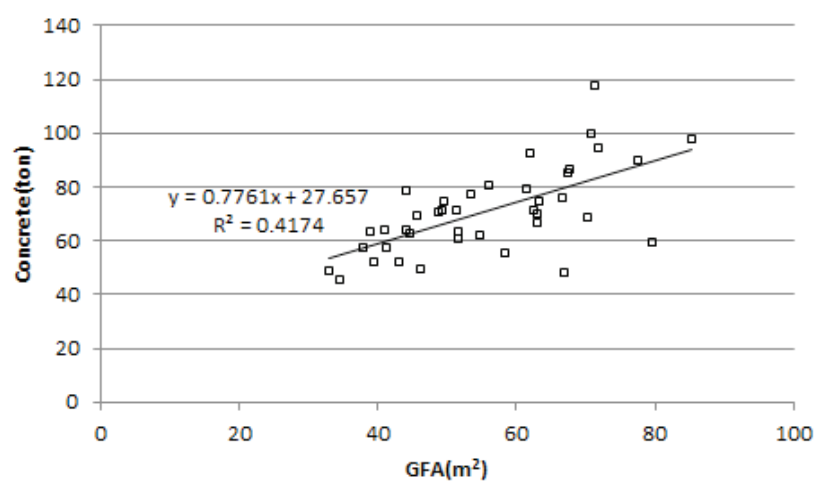

Figure 24. Distribution of Waste Concrete B-type in wood building

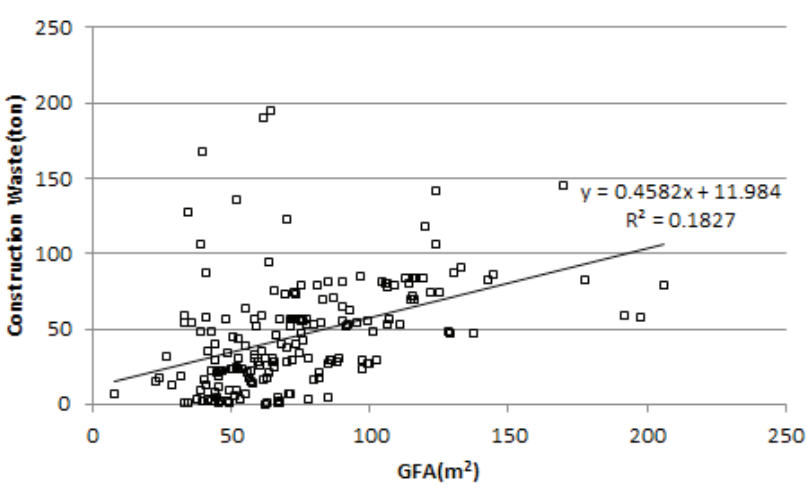

Figure 25. Distribution of Construction Waste in wood building

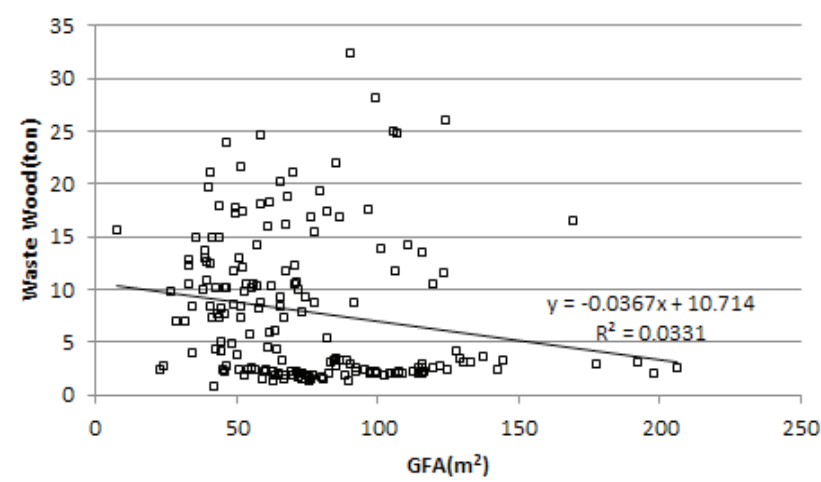

Figure 26. Distribution of Waste Wood in wood building

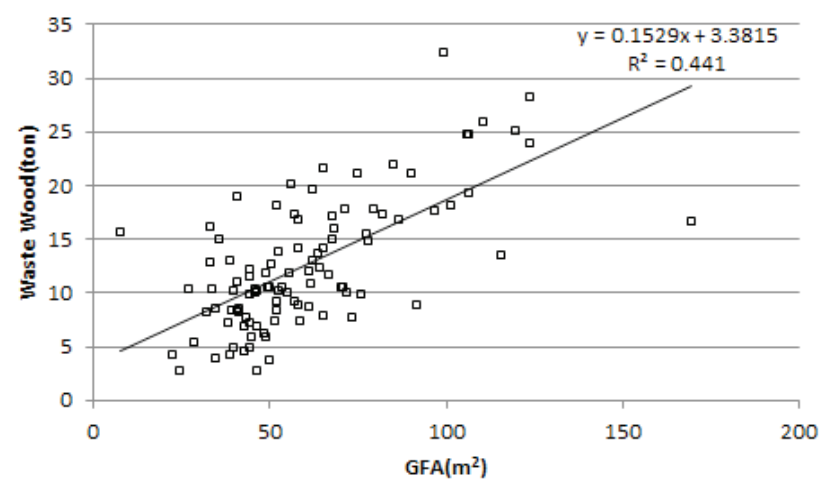

Figure 27. Distribution of Waste wood C-type in wood building

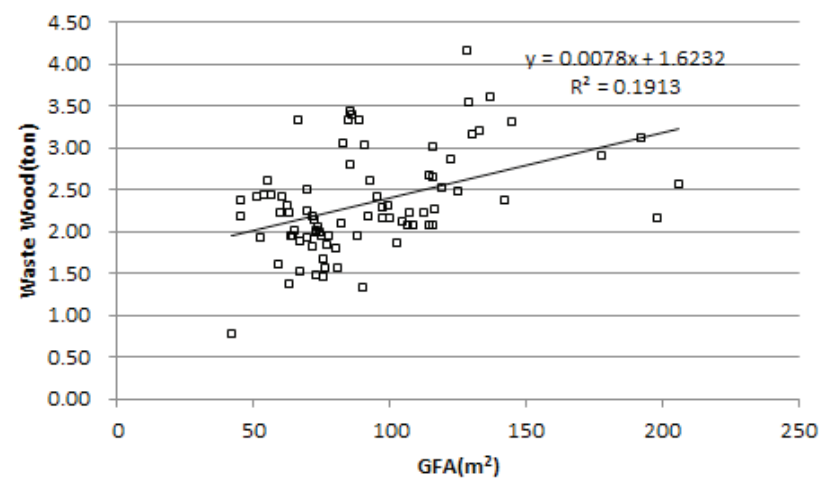

Figure 28. Distribution of Waste Wood D-type in wood building 
In terms of distribution of waste wood generation of timber buildings, it showed a negative correlation to generation distribution like waste concrete. Accordingly, this study prepared the distribution again by separating it to 2 types as percentage of waste wood generated according to the total area, and examined the correlation.

As shown in Fig. 27 and 28, generation volume of waste wood of timber buildings which showed a negative correlation as shown below was found to have a positive correlation. Based on this, Table 6 shows photos of representative buildings for each type.

Table 6. Separation of Type per Distribution of Waste Concrete of Timber Buildings
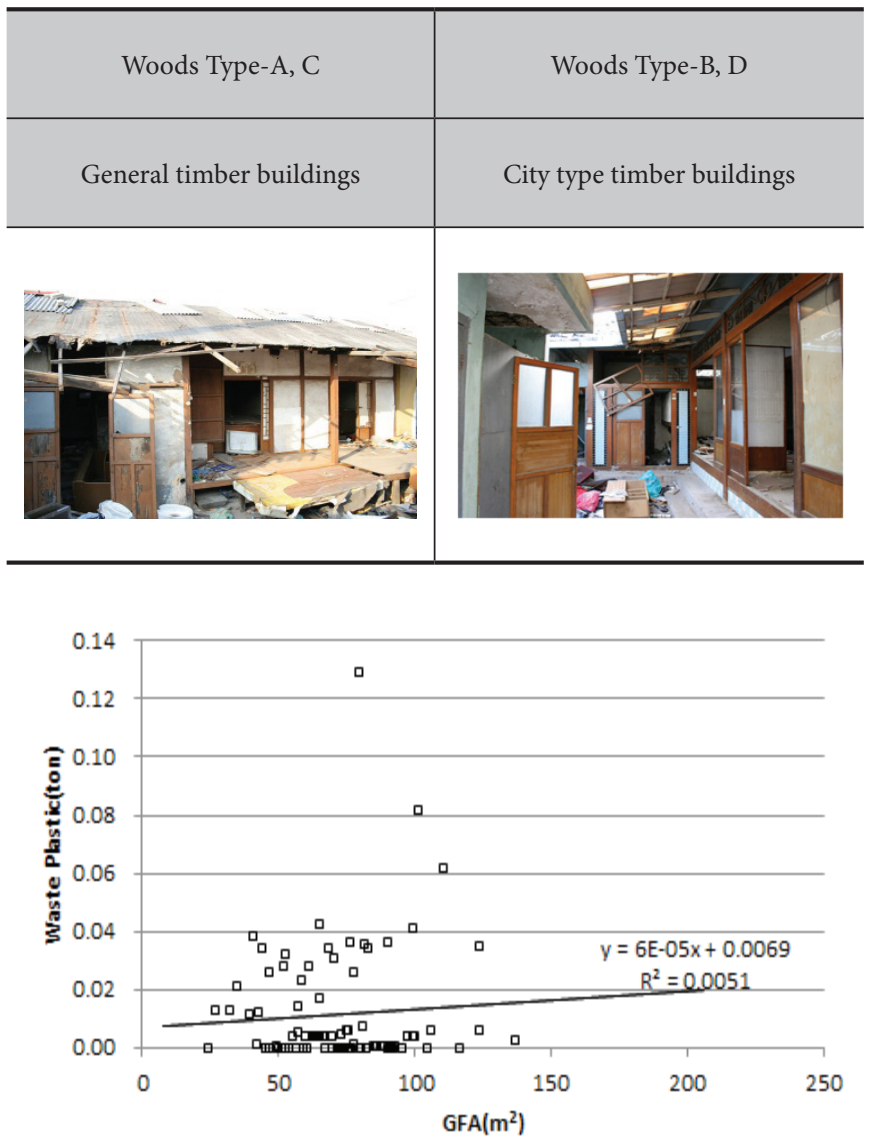

Figure 29. Distribution of Waste Plastic in wood building

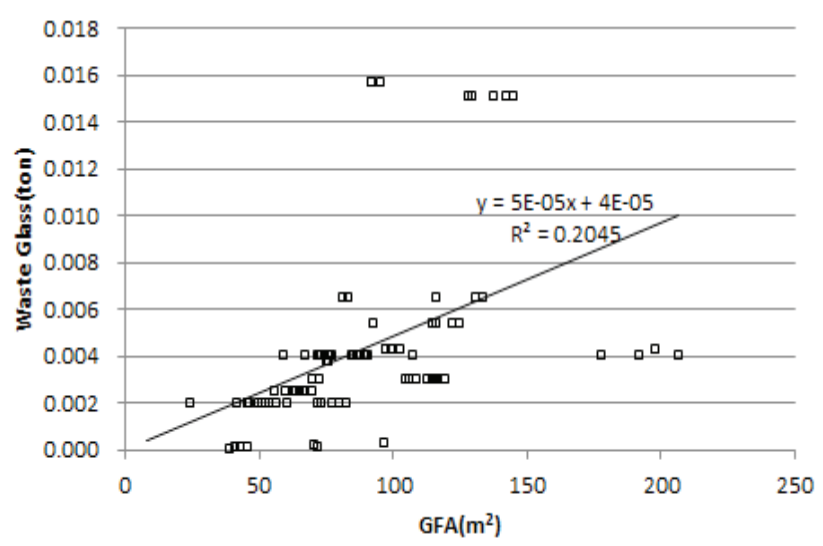

Figure 30. Distribution of Waste Glass in wood building

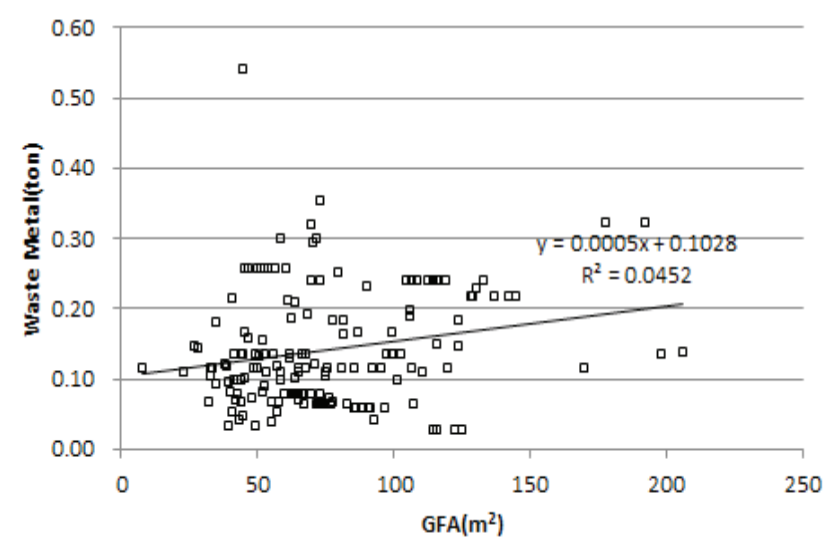

Figure 31. Distribution of Waste Metal in wood building

\section{CONCLUSION}

The final stage to complete a true resource circulation system in the construction industry must be the proper treatment and recycling of construction waste that occur in the demolition stage, the final stage in the building lifecyle.

Conclusions of this study are as follow:

In general, building construction waste in the total building area has a positive $(+)$ correlation. However, some wood buildings have a negative (-) correlation depending on the properties of construction waste.

(2) When the correlation is found to be negative as a result of classifying the building according to the main structure under building register like wood building, it was possible to consider such distribution as a Type-A traditional wood house and Type-B wood house adapted to city environment (for example, expansion of warehouses, bathrooms or walls with blocks or bricks).

(3) The distribution and regression formula of cement brick construction waste and waste concrete were found to be more suitable than construction waste or waste concrete of other structures.

In the demolition stage of building, there are many buildings in the housing environment amelioration district so that it is not easy to estimate the generation volume of construction waste. In general, the basic unit of construction waste that is used as the framework to estimate generation volume of construction waste is estimated by multiplying the constant by the total building floor area. There was no choice but to accept considerable errors.

For wood buildings that are about $23 \%$ of the buildings under this survey, this study found out that the generation pattern of waste concrete and waste wood would differ depending on the type of waste.

Further studies should examine and enunciate complicated factors such as building usage and construction year in addition to feature of construction waste, depending on the total building floor area and structure, resulting in a more accurate estimation of generation volume of construction waste. 


\section{REFERENCES}

Enforcement Regulations of Act on the Promotion of Saving and Recycling of Resources (2010)

The Ministry of Environment, Generation and Treatment Status of National Wastes (2010)

Korea Recycling, Guideline for Recycling of Construction Wastes and Recycling Plans (1995)

Seoul Development Institute, (1995) Proper Treatment and Recycling of Construction Wastes

The Ministry of Construction and Transportation, (1995) A Study on Recycling System of Construction Waste and Recycle Technology Development

LHI (Housing Institute, Korea Housing Corporation)(I), (1997) A Study on Treatment of Construction Wastes and Recycling Plan

Korea Institute of Construction Technology, (2000) Construction By-product Utilization Technology

LHI (Korea Land Corporation), (2000) A Study on Recycling and Treatment of Wastes from Bucheon Sangdong District

The Ministry of Environment, (2001) A Study on Demand and Detail Design for 2nd Nationwide Waste Statistics Survey

The Ministry of Environment, (2004) A Study on Calculation of Basic Unit and Separated Collection of Construction Wastes

The Ministry of Construction and Transportation, (2004) Development of system and demolition technology for improved utilization of demolition debris of apartment house

The Ministry of Construction and Transportation, (2005) A Study on Quality Evaluation and Management Plan of Recycled Aggregate Concrete

LHI (Korea Housing Corporation), (2006) Guideline on Management of Wastes at Construction Site

Korea Recycled Construction Resource Institute, (2006) Technology for production and utilization of construction wastes and recycled aggregates

The Ministry of Environment, (2006) Basic Plan on Recycling of Construction Wastes

Korea Environment Institute, (2006) Plans for Resource Recycling Policy for Sustainable Material Management

The Ministry of Environment, (2008) Comprehensive Measures for Recycling Wastes into Energy

Construction Waste Recycling Institute, (2006) Policy of Construction Waste Recycling and Trend of Technology Development

Construction Waste Recycling Institute, (2008) Trend of Technology Development of Construction Waste Recycling Production System for Resource Circulation

The Ministry of Environment (2010) Collection on International Seminar and Excellent Utilization Contest for Making Global Resource from Construction Wastes

Korea Institute of Construction Technology, (2009) Standard of Construction Estimation

Son, Byeung-Hun, Bang, Jong-Dae, and Hong, Won-Hwa, (2006) "A Study on Type of Construction Wastes Generated in Housing Environment Amelioration District for Calculation of Unit Base of Construction Waste" Architectural Institute of Korea

(Received April 25, 2011/Accepted January 26, 2013) 